\title{
Waste disposal of small wine and liquor agroindustry into tributaries of the Soturno and Jacuí rivers, Rio Grande do Sul, Brazil
}

\author{
Presencia de relaves de la pequeña agroindustria de vinos y \\ licores en afluentes de los ríos Soturno y Jacuí, Rio Grande do Sul, Brasil. \\ Daniela Krolow ${ }^{1}$; *Ivan R.C. Krolow*; Copetti, A.C. ${ }^{2}$; Danilo Rheinheimer dos Santos ${ }^{3}$
}

\begin{abstract}
The reduction of water quality typically starts in small streams and rivers; tributaries interconnected to major rivers. In this regard, this study aimed to investigate waste disposal of small wine and liquor agribusinesses by monitoring the water quality of two streams, tributaries of the Soturno and Jacuí rivers, located in the Quarta Colônia region the state of Rio Grande do Sul (RS), Brazil. We began monitoring water quality in July 2008 and continued uninterruptedly until May 2009. We collected water samples at three different locations (source, upstream, and downstream) in triplicate, totaling 162 samples. We investigated 24 variables that makeup chemical, physical and biological parameters of water quality. With the results, we concluded that the diffuse sources of pollution in the "Liquor stream" are associated with wastewater of small agribusinesses and nearby residences, in contrast, the source of the "Wine stream" showed the most chemical changes in water quality, and whose diffuse sources of pollution are more associated with agricultural activity than the small agribusinesses activity. The variables of chemical and biological oxygen demand, dissolved oxygen, total iron, total manganese, and total phosphorus presented values higher than those of Class II waters in both streams. Therefore, small agribusinesses need to adequately dispose of the waste in order to meet existing legislation comprehensively.

Key words: Food, waste, treatment, legislation.
\end{abstract}

\section{RESUMEN}

La reducción de la calidad del agua por lo general comienza en pequeños arroyos y ríos; afluentes que están interconectados para llegar a los principales cauces. Este estudio tiene como objetivo investigar la disposición de residuos en la pequeña agroindustria de vinos y licores en afluentes del Río Soturno y Río Jacuí. Las corrientes que reciben los residuos de las actividades agroindustriales (licores y vinos), ubicado en la región de la cuarta colonia de inmigrantes italianos en Rio Grande do Sul (Brasil) fueron monitoreadas. Este proceso comenzó en 07/2008 y continuó ininterrumpidamente hasta 05/2009. Las muestras de agua fueron recolectadas en tres puntos diferentes (al este, aguas arriba y abajo) por triplicado, por un total de 162 muestras. Se investigaron 24 que componen los parámetros químicos, físicos y biológicos de la calidad del agua. Con los resultados, concluimos que las fuentes difusas de contaminación en la "Corriente de licor" están asociadas con aguas residuales de pequeños agronegocios y residencias cercanas, en contraste, la fuente de la "Corriente del vino" mostró la mayor cantidad de cambios químicos en la calidad del agua, y cuyas fuentes difusas de contaminación están más asociadas a la actividad agrícola que a la pequeña actividad agroindustrial. Las variables de demanda química y biológica de oxígeno, oxígeno disuelto, hierro total, manganeso total y fósforo total presentaron valores superiores a los de las aguas Clase II en ambos arroyos. Por lo tanto, las pequeñas empresas agrícolas deben eliminar adecuadamente los desechos para cumplir de manera integral la legislación existente.

Palabras clave: Alimentos, residuos, tratamiento, legislación.

\section{Introduction}

The different realities of production systems and different loads of contaminants released into the environment have been of concern to the scientific community. For this reason, in recent years, growing concern over water quality has been observed, A significant number of institutions and researchers

\footnotetext{
Departamento de Solos, Universidade Federal de Santa Maria - RS, Brazil.

Universidade Federal do Pampa, Campus São Gabriel - RS, Brazil.

3 Departamento de Solos, Universidade Federal de Santa Maria - RS, Brazil.

* Corresponding author: mailto:ikrolow55@gmail.com, ikrolow55@gmail.com
}

Fecha de Recepción: 30 de Marzo, 2019.

Fecha de Aceptación: 05 de Enero, 2020. 
have been engaged in searching for information aimed at understanding the various relationships and interrelationships of production systems in varied ecosystems, as well as waste disposal into bodies of lentic and lotic water in light of growing environmental pollution (Menezes et al., 2014; Fia et al., 2015; Pereira et al., 2016). Pinheiro et al. (2014) proposed changes in the patterns of water quality in a river basin occur due to diverse factors and their relationships.

Activities of food production and processing of vegetable or animal raw materials may become efficient causes of pollution, point and diffuse water contamination sources. The source points of water pollution are those in which waste from the discharge point is visible, while diffuse sources do not have a specific pollutant discharge point (Andrade et al., 2016).

In this context, rural agro-industry activities have also been identified as point and diffuse sources of contamination of water bodies, given the growing number of small rural businesses, especially in the state of Rio Grande do Sul (RS).

Overall, the impact on water quality of a particular water body by wastewater will depend on its concentration, frequency, and also its physical, chemical, and biological characteristics (Lima et al., 2016). In this regard, Costa and Ferreira (2015) suggested that the main sources of water pollution are plant decomposition and soil erosion, domestic and industrial wastewater, and animal waste, pesticides, and fertilizers. The diffuse contribution of substances different from agroindustry activity, especially those residuary of no-till areas, residences, rejected in natural drainage systems such as streams and rivers, contribute to reduced self-purification capacity of a hydric system (Souza et al., 2014). Vinasse and wastewaters from cleaning of equipment used to produce concentrated and diluted juice and liquors, together or separately, can reduce the self-purification capacity of lotic environments.

According to Ahmed et al. (2013); Zúñica et al. (2013) and Ortegón et al. (2014), vinasse, besides having the ability to reduce the selfpurification capacity of the liquid medium, also causes oxygen depletion, $\mathrm{pH}$ reduction, and increased biochemical oxygen demand, among other things. Therefore, water quality monitoring through the assessment of physical, chemical, and microbiological parameters is fundamental.
In this regard, this study aimed to analyze the water quality of two streams, which are tributaries of the Soturno and Jacuí rivers, focusing on waste disposal of small wine and liquor agroindustry.

\section{Material and Methods}

The study took place in the Quarta Colônia region located between the plateau and central depression of the state of Rio Grande do Sul, limited by the Alto Jacuí, Baixo Jacuí and VacacaíVacacaí-Mirim basins. The economy of this region is characterized by family farming activities, such as vegetables and fruits, rice, soybean, and tobacco, and small agroindustry of liquors, juices, wines, sausages, and preserves. The climate is Cfa according to the Köppen classification. The average annual minimum temperature is $\cong 15^{\circ} \mathrm{C}$, and the average annual maximum temperature is $\cong$ $25^{\circ} \mathrm{C}$. The average annual rainfall is $\cong 1750 \mathrm{~mm}$. The soils in this region are young, very fragile, and distributed in fairly rugged terrain.

We randomly chose two small agribusinesses whose industrial products were of plant origin to evaluate the impact of their industrial activity on the water quality of two streams of the Soturno and Jacuí rivers. The first small agribusiness we selected is located in the city of São João do Polêsine (liquor production), which disposes its waste into what we called the "Liquor stream" (a tributary of the Jacuí river). The second agribusiness (wine production), located in the city of Ivora, disposes its waste into the "Wine stream" (a tributary of the Soturno river).

\section{Waste treatment}

The liquor business's main products are juices and liquors, generating wastewater from the aseptic treatment of raw materials and cleaning of the equipment. Wastewater is released in the shared treatment system of domestic waste, which consists of septic tanks. The main industrial products of the wine business are wines and cachaça (traditional Brazilian liquor), and it generated significant quantities of solid and liquid waste. Waste from vinasse and water from the aseptic treatment of raw materials and cleaning of the equipment and the premises are disposed onto the soil properties and later drained into the "Wine stream". 


\section{Conducting of the collections}

Water sampling during the experiment was carried out from September 2008 until May 2009. Table 1 shows the locations of the collection in more detail, and the number of samples taken in each stream.

\section{Analytical procedures}

Water sampling of the different streams and their respective locations were assessed by routine laboratory analytical principles described in Table 2 , except for the variables that make up the chemical parameters of dissolved oxygen (DO) and water temperature, which were evaluated in situ.

Laboratory tests were determined in triplicate $(\mathrm{n}=3)$ and accompanied by a blank analytical test. The parameters obtained here were compared to the values recommended by Resolution $\mathrm{N}^{\circ} 357$ (2005) of the National Environment Council (Conselho Nacional do Meio Ambiente - CONAMA).

\section{Statistical analysis}

The values of the variables of chemical, physical and biological parameters were subjected to statistical analysis.

Descriptive analysis was based on average indicators $(x)$, standard deviation $(\sigma)$, standard error $( \pm)$, minimum and maximum values, and amplitude. The Tukey test determined the comparison of each variable's means at $5 \%$ probability [Statistic software version 7.0 (STATSOFT, 2004). Afterward, the values of the 24 variables investigated were treated based on $\log _{10}$ to linearize data. The standard values were subjected to Kaiser-Meyer-Olkin (KMO) and Bartlett sphericity tests at 5\% significance (BioEstat Software, version 5.0).

Later, the data were summarized by factor analysis. We considered the factors that accumulated variance $>60 \%$ of the dataset. The load factor adopted as determining a factor started at $\geq 0.5$ because of the high variation of water quality parameters in rivers of natural drainage.

\section{Results}

The results of chemical, physical, and biological parameters of water investigated in the agribusinesses streams will be presented and discussed next.

\section{"Liquor stream"}

The values of EC, COD, Turbidity and $\mathrm{C}_{\text {total }}$ obtained in P1, P2 and P3 of the "Liquor stream" presented statistical differences by Tukey test $\left(\mathrm{p}_{\text {value }}<0.05\right)$. We observed that EC values were lower in $\mathrm{P} 1(x=50.00 ; \sigma=7.50)$ and $\mathrm{P} 2(x=62.00$; $\sigma=6.21$ ) (Table 3). In relation to COD, there is a high amount of oxygen consumed to oxidize the organic matter found in $\mathrm{P} 2(x=128.22 ; \sigma=58.98)$ and $\mathrm{P} 3(x=143.71 ; \sigma=87.66)$.

This increase in COD values in $\mathrm{P} 2$ and $\mathrm{P} 3$ were $320.63 \%$ and $359.36 \%$, respectively. Additionally, in order to relate COD values with BOD, we observed low values, which correspond to 2.28 (P1), 2.50 (P2), and 2.86 (P3). BOD values obtained were between 17.5 and $51.25 \mathrm{mg}^{-1}$, which shows a high amplitude of $33.75 \mathrm{mg}^{-1}$ (Figure 1).

Table 1. Planning and location of water sampling in the streams. Quarta Colônia, RS.

\begin{tabular}{|c|c|c|c|c|c|c|}
\hline Locations & Sample/Month & Latitude & Longitude & Altitude (m) & Altitude* & Distance/Slope \\
\hline & & \multicolumn{5}{|c|}{ Small family agribusiness - Liquors } \\
\hline Source (PL1) & $3 \times 9$ & $-29.651466 * *$ & -53.529805 & 250 & & \\
\hline Before (PL2) & $3 \times 9$ & -29.652913 & -53.525855 & 155 & 97 & $1000 / 10$ \\
\hline After (PL3) & $3 \times 9$ & -29.653030 & -53.525680 & 153 & & \\
\hline \multicolumn{7}{|c|}{ Small family agribusiness - Wines } \\
\hline Source (PW1) & $3 \times 9$ & -29.513975 & -53.514258 & 252 & & \\
\hline Before (PW2) & $3 \times 9$ & -29.516561 & -53.514805 & 213 & 53 & $500 / 11$ \\
\hline After (PW3) & $3 \times 9$ & -29.517908 & -53.514527 & 199 & & \\
\hline
\end{tabular}

* Altitude, distance and slope values represent the difference between values at the source and waste disposal point of the agroindustry. ${ }^{* *}$ Garmin $76 \mathrm{Cx} \pm 3 \mathrm{~m}$. 
Table 2. Parameter of quality of water, methods analytic and limits preconized through legislation Brazilian. 2016.

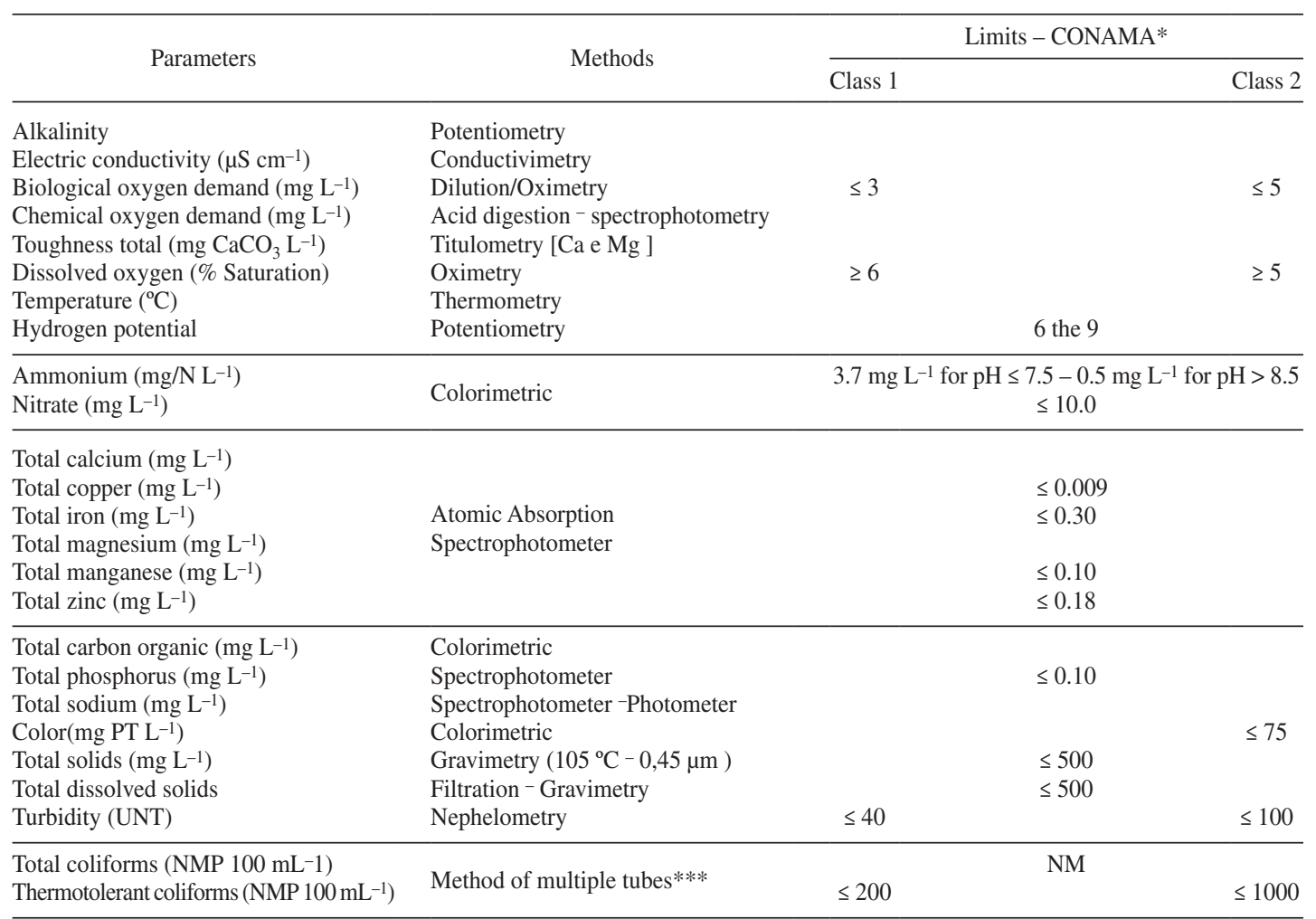

* National Environmental Council; **The culture medium used was enriched selective broth $-\mathrm{pH} 6,8$ a $25^{\circ} \mathrm{C}$ “ Fluorocult ${ }^{\circ} \mathrm{LMX}$ broth (Merck, Germany)"; ***Standard Methods for the Examination of Water and Wastewater (APHA; AWWA; WPCF, 2005); NM - Not mentioned.

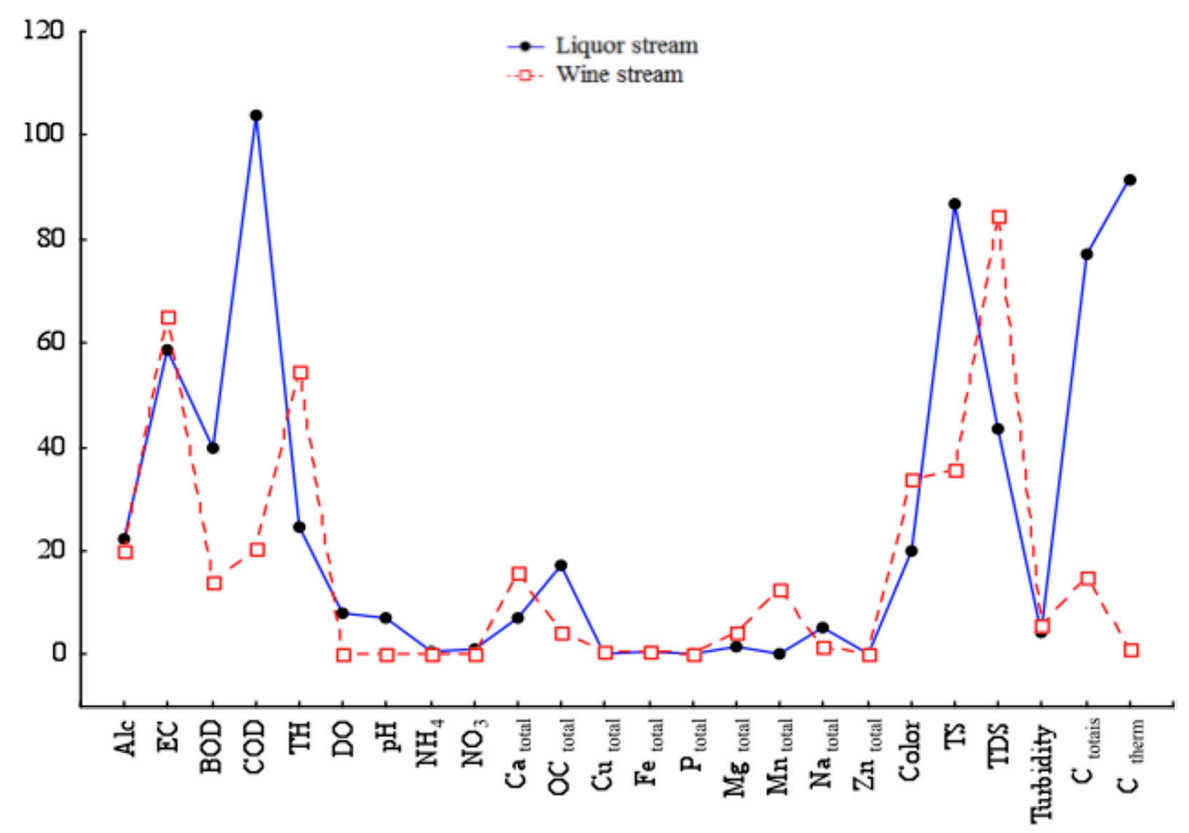

Figure 1. Amplitude of the variables that make up water quality parameters. Quarta Colônia/RS. 
Table 3. Mean values and standard error $( \pm)$ of the chemical, physical and biological parameters of the Liquor and Wine streams. Quarta Colônia/RS.

\begin{tabular}{|c|c|c|c|c|c|c|}
\hline \multirow{2}{*}{ Parameters } & \multicolumn{3}{|c|}{ Liquor } & \multicolumn{3}{|c|}{ Wine } \\
\hline & Location 1 & Location 2 & Location 3 & Location 1 & Location 2 & Location 3 \\
\hline & \multicolumn{6}{|c|}{ Chemical } \\
\hline $\mathrm{Alc}\left(\mathrm{mg} \mathrm{L}^{-1} \mathrm{de} \mathrm{CaCO}_{3}^{-}\right)^{* *}$ & $20.93 \pm 1.37$ & $22.34 \pm 0.69$ & $23.53 \pm 0.82$ & $69.86 \pm 2.15^{\mathrm{a}}$ & $49.99 \pm 5.00^{\mathrm{b}}$ & $51.50 \pm 2.18^{\mathrm{b}}$ \\
\hline $\mathrm{EC}\left(\mu \mathrm{Sm} \mathrm{cm}^{-1}\right)$ & $50.00 \pm 1.44 \mathrm{~b}^{*}$ & $62.00 \pm 1.19^{\mathrm{b}}$ & $64.00 \pm 0.99^{\mathrm{a}}$ & $138.00 \pm 3.45^{\mathrm{a}}$ & $73.00 \pm 4.36^{c}$ & $107.00 \pm 3.29^{\mathrm{b}}$ \\
\hline $\mathrm{BOD}\left(\mathrm{mg} \mathrm{L}^{-1}\right)$ & $17.50 \pm 0.20$ & $51.25 \pm 10.16$ & $50.25 \pm 0.67$ & $18.00 \pm 0.21$ & $31.8 \pm 4.83$ & $30.23 \pm 4.77$ \\
\hline $\operatorname{COD}\left(\mathrm{mg} \mathrm{L}^{-1}\right)$ & $39.99 \pm 11.78^{b}$ & $128.22 \pm 11.35^{\mathrm{a}}$ & $143.71 \pm 16.87^{a}$ & $42.70 \pm 9.12$ & $41.12 \pm 6.65$ & $61.37 \pm 5.91$ \\
\hline $\mathrm{TH}\left(\mathrm{mgCaCO}_{3} \mathrm{~L}^{-1}\right)$ & $21.71 \pm 0.84$ & $26.41 \pm 1.37$ & $26.18 \pm 1.21$ & $113.08 \pm 8.05^{\mathrm{a}}$ & $58.66 \pm 2.60^{b}$ & $65.26 \pm 2.26^{\mathrm{ab}}$ \\
\hline DO (\% Saturation) & $8.24 \pm 0.08$ & $7.86 \pm 0.08$ & $7.86 \pm 0.09$ & $7.65 \pm 0.13$ & $7.44 \pm 0.13$ & $7.37 \pm 0.33$ \\
\hline $\mathrm{pH}$ & $6.95 \pm 0.03$ & $7.14 \pm 0.01$ & $6.97 \pm 0.08$ & $7.22 \pm 0.03$ & $7.39 \pm 0.03$ & $7.38 \pm 0.06$ \\
\hline $\mathrm{NH}_{4}\left(\mathrm{mg} \mathrm{L}^{-1}\right)$ & $0.44 \pm 0.12$ & $0.54 \pm 0.06$ & $0.54 \pm 0.13$ & $0.27 \pm 0.03$ & $0.25 \pm 0.07$ & $0.30 \pm 0.08$ \\
\hline $\mathrm{NO}_{3}\left(\mathrm{mg} \mathrm{L}^{-1}\right)$ & $1.21 \pm 0.18$ & $1.21 \pm 0.12$ & $0.72 \pm 0.18$ & $0.28 \pm 0.05$ & $0.04 \pm 0.02$ & $0.04 \pm 0.02$ \\
\hline $\mathrm{Ca}_{\text {total }}\left(\mathrm{mg} \mathrm{L}^{-1}\right)$ & $6.15 \pm 0.28$ & $7.89 \pm 0.44$ & $7.82 \pm 0.38$ & $27.85 \pm 1.45^{\mathrm{a}}$ & $11.87 \pm 0.14^{b}$ & $15.94 \pm 0.61^{\mathrm{b}}$ \\
\hline $\mathrm{OC}_{\text {total }}\left(\mathrm{mg} \mathrm{L}^{-1}\right)$ & $17.12 \pm 2.11$ & $17.40 \pm 2.18$ & $17.75 \pm 2.43$ & $14.81 \pm 2.28$ & $19.25 \pm 2.26$ & $15.90 \pm 2.66$ \\
\hline $\mathrm{Cu}_{\text {total }}\left(\mathrm{mg} \mathrm{L}^{-1}\right)$ & $0.01 \pm 0.001$ & $0.06 \pm 0.02$ & $0.02 \pm 0.01$ & $0.15 \pm 0.04$ & $0.77 \pm 0.22$ & $0.02 \pm 0.01$ \\
\hline $\mathrm{Fe}_{\text {total }}\left(\mathrm{mg} \mathrm{L}^{-1}\right)$ & $1.00 \pm 0.16$ & $0.66 \pm 0.09$ & $0.69 \pm 0.13$ & $0.69 \pm 0.001$ & $1.28 \pm 0.01$ & $1.26 \pm 0.001$ \\
\hline $\mathrm{P}_{\text {total }}\left(\mathrm{mg} \mathrm{L}^{-1}\right)$ & $0.13 \pm 0.001$ & $0.15 \pm 0.01$ & $0.80 \pm 0.18$ & $0.11 \pm 0.01$ & $0.13 \pm 0.02$ & $0.03 \pm 0.001$ \\
\hline $\mathrm{Mg}_{\text {total }}\left(\mathrm{mg} \mathrm{L}^{-1}\right)$ & $1.54 \pm 0.04$ & $1.63 \pm 0.08$ & $1.61 \pm 0.07$ & $10.57 \pm 1.28$ & $7.04 \pm 0.58$ & $6.18 \pm 0.59$ \\
\hline $\mathrm{Mn}_{\text {total }}\left(\mathrm{mg} \mathrm{L}^{-1}\right)$ & $0.26 \pm 0.07$ & $0.08 \pm 0.02$ & $0.10 \pm 0.02$ & $3.69 \pm 0.01^{b}$ & $11.55 \pm 0.27 \mathrm{a}$ & $16.48 \pm 0.48^{\mathrm{a}}$ \\
\hline $\mathrm{Na}_{\text {total }}\left(\mathrm{mg} \mathrm{L}^{-1}\right)$ & $4.49 \pm 0.39$ & $5.11 \pm 0.30$ & $6.34 \pm 0.45$ & $7.57 \pm 0.57$ & $6.10 \pm 0.41$ & $6.39 \pm 0.36$ \\
\hline \multirow[t]{2}{*}{$\mathrm{Zn}_{\text {total }}\left(\mathrm{mg} \mathrm{L}^{-1}\right)$} & $0.07 \pm 0.01$ & $0.08 \pm 0.02$ & $0.09 \pm 0.02$ & $0.09 \pm 0.02$ & $0.13 \pm 0.03$ & $0.08 \pm 0.02$ \\
\hline & \multicolumn{6}{|c|}{ Physical } \\
\hline Color(mg PT L $\left.{ }^{-1}\right)$ & $18.75 \pm 0.47$ & $22.50 \pm 1.86$ & $18.75 \pm 0.47$ & $1.25 \pm 0.48^{b}$ & $27.50 \pm 3.39^{a}$ & $35.00 \pm 1.08^{\mathrm{a}}$ \\
\hline $\mathrm{TS}\left(\mathrm{mg} \mathrm{L}^{-1}\right)$ & $55.71 \pm 8.26$ & $167.14 \pm 25.41$ & $37.14 \pm 10.72$ & $104.29 \pm 9.83$ & $68.57 \pm 13.59$ & $68.57 \pm 13.59$ \\
\hline TDS (mg L-1) & $23.57 \pm 4.94$ & $32.86 \pm 5.88$ & $74.29 \pm 16.58$ & $59.64 \pm 4.82$ & $16.19 \pm 2.84$ & $100.71 \pm 17.64$ \\
\hline \multirow[t]{2}{*}{ Turbidity (NTU) } & $6.10 \pm 0.19^{a}$ & $3.48 \pm 0.19^{\mathrm{b}}$ & $3.90 \pm 0.19^{a}$ & $0.93 \pm 0.17^{b}$ & $6.45 \pm 0.45^{\mathrm{a}}$ & $2.37 \pm 0.35^{b}$ \\
\hline & \multicolumn{6}{|c|}{ Biological } \\
\hline $\mathrm{C}_{\text {total }}\left(\mathrm{NMP} 100 \mathrm{~mL}^{-1}\right)$ & $0.04 \pm 0.89^{b}$ & $115.54 \pm 25.55^{\mathrm{a}}$ & $115.93 \pm 25.46^{\mathrm{a}}$ & $11.53 \pm 2.56$ & $1.35 \pm 30.00$ & $16.41 \pm 36.47$ \\
\hline $\mathrm{C}_{\text {therm }}\left(\mathrm{NMP} 100 \mathrm{~mL}^{-1}\right.$ ) & nd & $5.75 \pm 2.21$ & $269.20 \pm 102.58$ & $0.95 \pm 0.21$ & nd & $1.93 \pm 0.74$ \\
\hline
\end{tabular}

*Values in the row line of the same letter do not differ statistically by Tukey test at $5 \%$ probability. **Alc- Alkalinity; EC-Electric conductivity; BOD-Biological oxygen demand; COD-Chemical oxygen demand; TH- Toughness total $_{\text {; }}$ DO- Dissolved oxygen; pH-Potential Hydrogen; $\mathrm{NH}_{4}$-Ammonium; $\mathrm{NH}_{3}$-Nitrate; $\mathrm{Ca}_{\text {total }}$-Total calcium; $\mathrm{OC}_{\text {total }}$-Total organic carbon; $\mathrm{Cu}_{\text {total }}$-Total copper; $\mathrm{Fe}_{\text {total }}$-Total iron; $\mathrm{P}_{\text {total }}$-Total phosphorus; $\mathrm{Mg}_{\text {total }}$-Total magnesium; $\mathrm{Mn}_{\text {total }}$-Total manganese; $\mathrm{Na}_{\text {total }}$-Total sodium; $\mathrm{Zn}_{\text {total }}$-Total zinc; TS-Total solids; TDS-Total dissolved solids; $\mathrm{C}_{\text {total }}$-Total coliforms e $\mathrm{C}_{\text {therm }}$-Thermotolerant coliforms; nd-Not detected. Averages of 81 samples collected during the experimental period (nine months) en each stream.

We did not find BOD values within the limits recommended by the resolution for freshwater classes I and II in any of the locations sampled in this study (Table 2).

The lowest Turbidity value was observed in P2 $(x=3.48 ; \sigma=1.00)$. Although the same statistical significance represents turbidity values found in $\mathrm{P} 1$ and $\mathrm{P} 3$, we found that the value obtained at the SOURCE/SPRING corresponded to $36.06 \%$ more than in P3. Still, the most significant Turbidity expression in P1 was visually identified, which was not clearly evident in the other sampled locations.
The biggest concentrations $\mathrm{C}_{\text {total }}$ were found in $\mathrm{P} 2$ and $\mathrm{P} 3$ of the "Liquor stream". The TH values were between 21.71 and $26.41 \mathrm{mg} \mathrm{L}^{-1}$, which confirms the soft water rating ( 0 to $50 \mathrm{mg}^{-1}$ ).

It was found that the DO values were not differing by presenting a small amplitude which corresponded to $0.38 \mathrm{mg}^{-1}$ (Figure 1). However, the values found in $\mathrm{P} 1(x=8.24 ; \sigma=0.41), \mathrm{P} 2(x=7.86$; $\sigma=0.40)$ e P3 $(x=7.86 ; \sigma=0.47)$ are considered high for Class II waters Stream Liqueurs.

The amplitude values $\left(0.10 \mathrm{mg}^{-1}\right)$ obtained for $\mathrm{NH}_{4}$ were considered very low. In general, the chemical variables $\mathrm{Ca}_{\text {total }}, \mathrm{OC}_{\text {total }}, \mathrm{Mg}_{\text {total }}, \mathrm{Na}_{\text {total, }}$, nnd 
$\mathrm{Zn}_{\text {total }}$, and the physical variable Color also showed small amplitude, showing similarity between the sampled locations.

Analyzing the $\mathrm{P}_{\text {total }}$ values of the locations, we confirmed that they are above the limits recommended by the resolution $\left(0.10 \mathrm{mg}^{-1}\right)$. Similarly, the water flow showed an increased $\mathrm{P}_{\text {total }}$ from the source to P3 with an increased amount equal to $615.38 \%$.

$\mathrm{Mn}_{\text {total }}$ values were above those recommended by the resolution in P1 and P3 in the "Liquor stream", and the largest amplitude value was conditioned by P1 $\left(0.26 \mathrm{mg}^{-1}\right)$.

TDS values showed that a gradient was formed between P1 ( $x=23.57 ; \sigma=25.69), \mathrm{P} 2$ ( $x=32.86$; $\sigma=30.56)$ and P3 ( $x=74.29 ; \sigma=86.18)$ with an amplitude between them corresponding to $50.72 \mathrm{mg}^{-1}$ (Figure 1).

\section{"Wine stream"}

The variables that make up the chemical and physical parameters that showed statistical differences in the "Wine stream" were Alc, EC, TH, $\mathrm{Ca}_{\text {total }}$ and $\mathrm{Mn}_{\text {total }}$, Color and Turbidity, respectively (Table 2). Regarding these chemical variables, the highest values were found in P1, except the $\mathrm{Mn}_{\text {total }}$.

The overall $\mathrm{Mn}_{\text {total }}$ content was lower in P1 $(x=3.69 ; \sigma=0.04)$ and higher in P2 $(x=11.55$; $\sigma=1.39)$ and P3 ( $x=16.48 ; \sigma=2.47)$ at 313.48 and $446.61 \%$, respectively. While the values of the physical parameters Color $(x=1.25 ; \sigma=2.50)$ and Turbidity ( $x=0.93 ; \sigma=0.87)$ in P1 were among the lowest found in the study.

The values of variables $\mathrm{DO}, \mathrm{NO}_{3}, \mathrm{Mg}_{\text {total }}, \mathrm{Na}_{\text {total }}$, and TS showed small amplitude (Figure 1), which were conditioned by the values obtained in P1.

We observed that the values of the variables BOD, pH, $\mathrm{OC}_{\text {total }}, \mathrm{Cu}_{\text {total }}, \mathrm{Fe}_{\text {total }}, \mathrm{P}_{\text {total }}, \mathrm{Zn}_{\text {total, }}$ and Turbidity raised the amplitude values downstream of $\mathrm{P} 1$ in $\mathrm{P} 2$.

While in the downstream FLOW of P2, we observed the highest amplitude values for the variables $\mathrm{NH}_{4}$, Color, TDS, $\mathrm{C}_{\text {total, }}$ and $\mathrm{C}_{\text {therm }}$ conditioned by values found in P3.

We should highlight that the values of $\mathrm{P}_{\text {total }}$ were between 0.03 and $0.13 \mathrm{mg}^{-1}$. The values found in $\mathrm{P} 1$ and $\mathrm{P} 2$ were above the limits recommended by the resolution (Table 1 ).

The amplitude of BOD values were high in the "Wine stream" and conditioned by the lowest value found in P1 ( $x=18.00 ; \sigma=1.08)$, and also due to the highest value observed in P2 ( $x=31.80$; $\sigma=25.12$ ). Incidentally, the BOD value found in P1 and $\mathrm{P} 3$ proved superior to the values recommended by the resolution (Table 2) for Class II waters in 3.6 and 6.36 times.

The DO values for the three sampled locations were also higher than those recommended by the resolution; while the amplitude value $(0.28)$ between locations was considered one of the smallest in this study, as shown in Figure 1.

\section{Global analysis}

After the individual analysis of the variables that make the water quality parameters, we sought a global, exploratory, and coordinated assessment since it was possible to identify the existence of high data variation in view of the standard deviation values and standard error some of the variables.

The standardized values of the 24 variables provided the correlation matrix shown in Table 4. Then the values were submitted to Kaiser-MeyerOlkin (KMO) and Bartlett tests. The KMO value was high and corresponded to 0.76, and the Bartlett test showed a high coefficient of maximum likelihood estimation (Phi $=245.2735$ and $\left.\mathrm{p}_{\text {-value }}<0.0001\right)$. These analyses allow us to infer that the summarization of data by factor analysis is appropriate.

Figure 2 shows the values and percentage of the accumulated variation in five (5) factors (a) the plot of the scores, (b) and collection locations plotted in the factorial plan (c).

We extracted two factors: the first eigenvalue $(\lambda 1=11.59)$ loaded $48.29 \%$ of the variance and the second eigenvalue $(\lambda 2=4.96) 20.66 \%$. Both factors accumulated $68.95 \%$ of the variance (Figure $2 a$ ).

In axis 1 , variance was represented by the values of 13 variables [Alc and $\mathrm{Mg}_{\text {total }}$ (0.99); $\mathrm{TH}(0.98)$; $\mathrm{Ca}_{\text {total }} ; \mathrm{Mn}_{\text {total }}$ (0.92); EC (0.88); $\mathrm{pH}(0.84) ; \mathrm{Na}_{\text {total }}$ (0.73); $\mathrm{Cu}_{\text {total }}(0.58) ; \mathrm{Zn}_{\text {total }}(0.45) ; \mathrm{Fe}_{\text {total }}(0.40) ; \mathrm{TS}$ (0.22) and TDS (0.18)].

In axis 2 , the arrangement in factorial plan was made up of 11 variables $\left[\mathrm{C}_{\text {total }}(-0.01)\right.$; $\mathrm{Col}(-0.42)$; BOD (-0.43); $\mathrm{CO}_{\text {total }}(-0.44)$; Turbidity $(-0.58)$; $\mathrm{C}_{\text {therm }}(-0.59)$; COD $(-0.60)$; $\mathrm{P}_{\text {total }}(-0.63)$; DO, $\mathrm{NO}_{3}(-0.80)$ and $\mathrm{NH}_{4}(-0.94)$ ] (Figure $2 \mathrm{~b}$ ).

Given the factorial analysis, we found a greater array of water quality parameters established by CONAMA in the "Liquor stream". The variables modeled for PL1 were Turbidity, an $\mathrm{OC}_{\text {total }}$ and 
Table 4. Matrix correlation of water quality parameters.

\begin{tabular}{|c|c|c|c|c|c|c|c|c|c|c|c|c|c|c|c|c|c|c|c|}
\hline & Alc & $\mathrm{EC}$ & BOD COD & $\mathrm{TH}$ & D0 & $\mathrm{pH}$ & $\mathrm{NH}_{4}$ & $\mathrm{NO}_{3} \mathrm{Ca}_{\text {total }} \mathrm{OC}_{\text {total }}$ & $\mathrm{Cu}_{\text {total }}$ & $\mathrm{Fe}_{\text {total }} \mathrm{P}$ & $\mathrm{P}_{\text {total }} \mathrm{M}$ & $\mathrm{Mg}_{\text {total }} \mathrm{I}$ & $\mathrm{Mn}_{\text {tota }}$ & $\mathrm{Na}_{\text {total }}$ & $\mathrm{Zn}_{\text {total }}$ Color & $\mathrm{TS}$ & TDS & Turbidity & $\mathrm{C}_{\text {total }} \mathrm{C}_{\text {therm }}$ \\
\hline Alc & 1.00 & & & & & & & & & & & & & & & & & & \\
\hline $\mathrm{EC}$ & 0.91 & 1.00 & & & & & & & & & & & & & & & & & \\
\hline BOD & -0.40 & -0.31 & 1.00 & & & & & & & & & & & & & & & & \\
\hline COD & -0.55 & -0.29 & 0.891 .00 & & & & & & & & & & & & & & & & \\
\hline $\mathrm{TH}$ & 0.99 & 0.95 & $-0.40-0.50$ & 1.00 & & & & & & & & & & & & & & & \\
\hline DO & -0.80 & -0.69 & $-0.15 \quad 0.15$ & -0.75 & 1.00 & & & & & & & & & & & & & & \\
\hline $\mathrm{PH}$ & 0.80 & 0.62 & $-0.03-0.36$ & 0.75 & -0.93 & 1.00 & & & & & & & & & & & & & \\
\hline $\mathrm{NH}_{4}$ & $-0.92-$ & -0.69 & $0.53 \quad 0.78$ & -0.87 & 0.72 & -0.81 & 1.00 & & & & & & & & & & & & \\
\hline $\mathrm{NO}_{3}$ & -0.77 & -0.55 & $0.09 \quad 0.44$ & -0.69 & 0.91 & -0.91 & 0.84 & 1.00 & & & & & & & & & & & \\
\hline $\mathrm{Ca}_{\text {total }}$ & 0.95 & 0.98 & $-0.39-0.40$ & 0.98 & -0.68 & 0.65 & -0.77 & $-0.57 \quad 1.00$ & & & & & & & & & & & \\
\hline $\mathrm{OC}_{\text {total }}$ & -0.45 & -0.73 & $0.51 \quad 0.19$ & -0.54 & 0.08 & -0.05 & 0.22 & $-0.04-0.67 \quad 1.00$ & & & & & & & & & & & \\
\hline $\mathrm{CU}_{\text {total }}$ & 0.59 & 0.33 & $0.02-0.32$ & 0.57 & -0.57 & 0.65 & -0.63 & $\begin{array}{lll}-0.51 & 0.46 & 0.28\end{array}$ & 1.00 & & & & & & & & & & \\
\hline $\mathrm{Fe}_{\text {total }}$ & 0.32 & 0.01 & $-0.27-0.59$ & 0.20 & -0.46 & 0.58 & -0.59 & $\begin{array}{lll}-0.76 & 0.04 & 0.28\end{array}$ & 0.15 & 1.00 & & & & & & & & & \\
\hline$P_{\text {total }}$ & -0.54 & -0.48 & $0.44 \quad 0.55$ & -0.51 & 0.48 & -0.68 & 0.60 & $0.57-0.47 \quad 0.43$ & -0.06 & -0.06 & 1.00 & & & & & & & & \\
\hline $\mathrm{Mg}_{\text {total }}$ & 1.00 & 0.87 & $-0.43-0.60$ & 0.98 & -0.79 & 0.81 & -0.95 & $\begin{array}{lll}-0.78 & 0.93 & -0.40\end{array}$ & 0.63 & 0.36 & $-0.55 \quad 1$ & 1.00 & & & & & & & \\
\hline $\mathrm{Mn}_{\text {total }}$ & 0.88 & 0.68 & $-0.41-0.67$ & 0.82 & -0.82 & 0.87 & -0.95 & $\begin{array}{lll}-0.94 & 0.72 & -0.21\end{array}$ & 0.48 & $0.72-$ & $-0.71 \quad 0$ & 0.90 & 1.00 & & & & & & \\
\hline $\mathrm{Na}_{\text {total }}$ & 0.81 & 0.87 & $-0.04-0.06$ & 0.84 & -0.69 & 0.49 & -0.57 & $-0.52 \quad 0.86-0.45$ & 0.43 & $-0.11-$ & $-0.05 \quad 0$ & 0.76 & 0.54 & 1.00 & & & & & \\
\hline $\mathrm{Zn}_{\text {total }}$ & 0.48 & 0.19 & $0.19-0.19$ & 0.42 & -0.61 & 0.57 & -0.56 & $\begin{array}{lll}-0.61 & 0.29 & 0.51\end{array}$ & 0.89 & 0.30 & 0.150 & 0.52 & 0.48 & 0.46 & 1.00 & & & & \\
\hline Color & -0.48 & -0.61 & $0.53 \quad 0.30$ & $-0.58-$ & -0.05 & 0.06 & 0.30 & $-0.17-0.67 \quad 0.68$ & -0.24 & $0.52-$ & $-0.06-0$ & -0.46 & -0.08 & -0.56 & $0.01 \quad 1.00$ & & & & \\
\hline TS & 0.17 & 0.26 & $0.04 \quad 0.03$ & 0.24 & -0.12 & 0.33 & -0.07 & $0.10 \quad 0.28-0.27$ & 0.35 & $-0.30-$ & $-0.40 \quad 0$ & 0.19 & -0.01 & -0.03 & $-0.08-0.27$ & 1.00 & & & \\
\hline TDS & 0.23 & 0.55 & $0.15 \quad 0.39$ & 0.27 & -0.28 & 0.02 & 0.08 & $\begin{array}{lll}-0.09 & 0.40 & -0.65\end{array}$ & -0.47 & $-0.25-$ & $-0.09 \quad 0$ & 0.14 & 0.08 & 0.55 & $-0.37-0.19$ & -0.16 & 1.00 & & \\
\hline Turbidity & -0.62 & -0.88 & $0.28 \quad 0.05$ & -0.71 & 0.31 & -0.23 & 0.32 & $0.08-0.84 \quad 0.90$ & -0.07 & 0.42 & $0.27-0$ & -0.57 & -0.26 & -0.73 & $0.16 \quad 0.79$ & -0.38 & -0.65 & 1.00 & \\
\hline $\mathrm{C}_{\text {total }}$ & 0.05 & 0.31 & $0.75 \quad 0.80$ & 0.11 & -0.35 & 0.12 & 0.29 & $0.03 \quad 0.21-0.13$ & 0.06 & -0.55 & $0.26-0$ & -0.01 & -0.21 & 0.48 & $0.08-0.05$ & 0.26 & 0.59 & -0.42 & 1.00 \\
\hline $\mathrm{C}_{\text {therm }}$ & $-0.50-$ & -0.30 & $0.73 \quad 0.86$ & $-0.48-$ & -0.20 & -0.51 & 0.68 & $0.37-0.40 \quad 0.25$ & -0.35 & -0.50 & $0.78-0$ & -0.55 & -0.60 & 0.08 & $\begin{array}{ll}-0.05 & 0.21\end{array}$ & -0.44 & 0.42 & 0.13 & $0.63 \quad 1.00$ \\
\hline
\end{tabular}

**Alc-Alkalinity; EC-Electric conductivity; BOD - Biological oxygen demand; COD - Chemical oxygen demand; TH - Toughness total $_{\text {; }}$ DO - Dissolved oxygen; $\mathrm{pH}$ - Potential Hydrogen; $\mathrm{NH}_{4}$-Ammonium; $\mathrm{NH}_{3}-$ Nitrate; $\mathrm{Ca}_{\text {total }}$ - Total calcium; $\mathrm{OC}_{\text {total }}$ - Total organic carbon; $\mathrm{Cu}_{\text {total }}$ - Total copper; $\mathrm{Fe}_{\text {total }}$ - Total iron; P Nitrate; $\mathrm{Ca}_{\text {total }}$ - Total phosphorus; $\mathrm{Mg}_{\text {total }}$ - Total magnesium; $\mathrm{Mn}_{\text {total }}-\mathrm{Total}$ manganase; $\mathrm{Na}_{\text {total }}$ - Total sodium; $\mathrm{Zn}_{\text {total }}$ - Total zinc; $\mathrm{TS}$ - Total solids; TDS - Total dissolved solids; $\mathrm{C}_{\text {total }}$ - Total colifors e $\mathrm{C}_{\text {therm }}$ - Thermotolerant coliforms.

Color. While in PL2 and PL3 the variables were DO, $\mathrm{P}_{\text {total }}, \mathrm{BOD}, \mathrm{NH}_{4}, \mathrm{NO}_{3}, \mathrm{C}_{\text {total }}, \mathrm{COD}$, and $\mathrm{C}_{\text {therm }}$. The other variables assessed in this study were related to the "Wine stream".

At P1 and P3 of the "Liquor stream", only two variables that make up the physical parameter (TDS and TS) are significantly related.

\section{Discussion}

\section{Liquor stream}

The EC values were higher in $\mathrm{P} 3$ of the "Liquor stream", although we did not observe significant differences between P1 and P2. It is clear that EC increased as the water stream moved away from the source.

The COD values were higher in $\mathrm{P} 2$ and $\mathrm{P} 3$. In this case, it is possible to speculate that water quality reduction is not directly related to agroindustry activity. Even with high amplitude between the sampled locations, it was clear that the diffuse source's contribution in this stream is greater than that of the point source. On the other hand, we observed a small value when COD is related to $\mathrm{BOD}$, which reinforces the hypothesis that there is a high load of biodegradable materials deposited in the stream, greater than its self-purification capacity.

Concerning Turbidity, the values show that in the source of the "Liquor stream", there is greater contribution of organic materials in suspension, mainly plant residues.

The highest values of $\mathrm{C}_{\text {total }}$ and $\mathrm{C}_{\text {therm }}$ in $\mathrm{P} 2$ and $\mathrm{P} 3$ are associated with the activities of agriculture and livestock, and the disposal of wastewater from residences and agribusinesses disposing of their waste in septic tanks of shared use and then deposited in the "Liquor stream". Regarding DO, the values did not show high amplitude, but they are above the limits recommended by the resolution (Table 2).

The variations in dissolved oxygen content and the quantities of coliforms (fecal and thermotolerant) 
found in the present study are similar to those found by Rixen et al. (2012). These authors warn that the deposition of organic matter in water bodies is used by microorganisms or even undergoes purely chemical oxidation.

$P_{\text {total }}$ values are above the levels recommended by the resolution. We also observed gradient formation from P1 to P3. The addition of the total $\mathrm{P}$ values in $\mathrm{P} 2$ was low but high in $\mathrm{P} 3$. The reduction in water quality in the "Liquor stream" seems to be more associated with diffuse pollution. Concerning the increase of total $\mathrm{P}$ in water, one should give special attention to wastewater from cleaning the premises and the equipment used in the agroindustry. Typically, products such as synthetic detergents, which are used in cleaning, contain mineral compounds, especially polyphosphate and orthophosphate (Gutiérrez et al., 2015; Rocha and Pereira, 2016).

Regarding TDS, the high amplitude value was conditioned by the value found in P3. As found in other variables, a gradient also formed from the "Liquor stream" source, which is related to waste deposited in the stream after P1.

In this regard, we refer to the considerations of Nascimento et al. (2015), who investigated the water quality of the Capivari and Bacuri streams in the state of Maranhão. The authors found TS values between 76 and $588 \mathrm{mg}^{-1}$, attributing the results to erosion caused by deforestation along the streams banks and domestic waste discarded in nature.

\section{Wine stream}

In general, the highest values of Alc, EC, TH, and $\mathrm{Ca}_{\text {total }}$ were found in $\mathrm{P} 1$. These results may be associated with anthropogenic actions in altitudes higher to those of the "Wine stream".

The upwelling of groundwater that originated and maintained the "Wine stream" is surrounded by riparian forest remnants. However, it did not secure the lowest values for these parameters. Similarly, the riparian forest also supplies organic materials, thereby contributing to the reduction in water quality.

Furthermore, Correia et al. (2015) reported that EC values above $100 \mu \mathrm{Sm} \mathrm{cm}^{-1}$ allow us to infer that there is a presence of diffuse source contaminants.

The authors investigated the water quality of the Peri-Poçu stream (a tributary of the Paraná River) and found values higher than those found in this study. They also emphasized that the diffuse contamination was due to agriculture, livestock, and industry.

Given the values of $\mathrm{BOD}, \mathrm{OC}_{\text {total }}, \mathrm{Cu}_{\text {total }}$, $\mathrm{Fe}_{\text {total, }}$ and $\mathrm{P}_{\text {total }}$, we found that their respective amplitude values were conditioned by the highest values found in $\mathrm{P} 2$. These observations are related to farming activities observed on the flanks of the "Wine stream". We should mention that in P3, the $\mathrm{P}_{\text {total }}$ did not exceed the limit of the resolution taken as reference in this study. Smaller $\mathrm{P}_{\text {total }}$ values in P3 are probably associated with the remaining riparian forest, which, although being a little more than $50 \mathrm{~m}$ in radius.

In general, the values of DO showed a small amplitude (Figure 1), allowing us to interpret that both streams' self-purification capacity was similar during the nine months of this study. According to Antunes et al. (2012), a water body's self-purification capacity can significantly reduce DO values.

The reduction in water quality in this stream was caused by agricultural activity and local geology since the arrangements of crop areas are at higher altitudes, promoting widespread contamination due to natural drainage toward the stream.

Regarding $\mathrm{Fe}_{\text {total }}$, higher values are typically observed in the water of streams nearby crops. As soil is eroded by rainwater, part of its elements translocates to the streams, raising the levels of various elements such as iron. High levels of iron and manganese are transferred into water bodies due to heavy rainfall, and as they are dissolved in water, they contribute to reaching higher Turbidity values, as shown in Table 2. These results agree partially with those found by Alves et al. (2008), who investigated the water quality of the Pirapó river in the city of Maringa (PR) and found higher Turbidity values of iron relationships and manganese, and also observed higher Color values.

\section{Global analysis}

The plotting of the variables EC, TDS, TS, $\mathrm{Ca}_{\text {total }}, \mathrm{Na}_{\text {total }}, \mathrm{TH}, \mathrm{Alc}$, and $\mathrm{Mg}_{\text {total }}$ is found in the same quadrant. In another NEARBY quadrant, the variables $\mathrm{pH}, \mathrm{Mn}_{\text {total }}, \mathrm{Zn}_{\text {total }}, \mathrm{Cu}_{\text {total }}$ e $\mathrm{Fe}_{\text {total }}$ are found. Both groups were grouped in the "Wine stream".

EC showed higher values in the "Wine stream", as previously mentioned (P1 and P3), which was confirmed in the arrangement plotted in Figure $2 b$, 

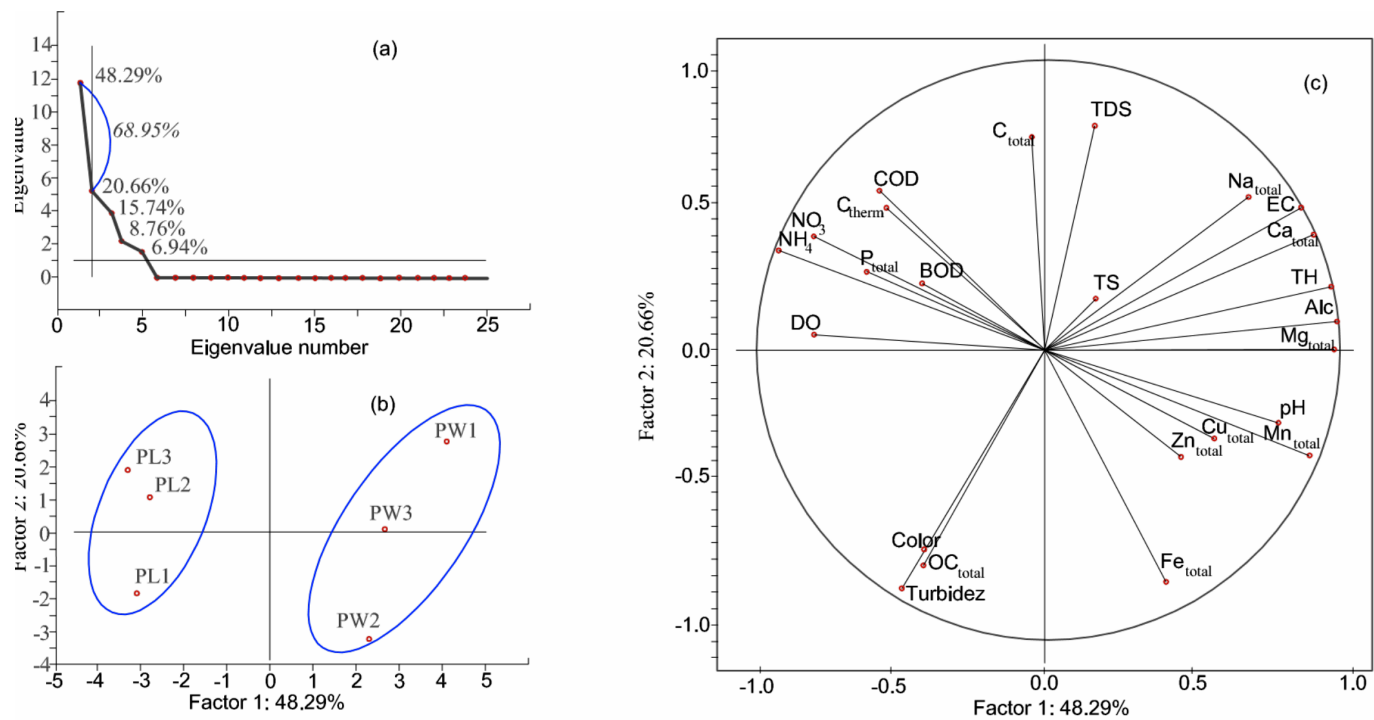

Figure 2. Scree plot obtained with the components (a), Biplot with the dispersion of the scores of the first two components (b), and projection of the sampled locations on the factorial plan (c). Quarta Colônia/RS.

*Alc-Alkalinity; EC-Electric conductivity; BOD-Biological oxygen demand; COD-Chemical oxygen demand; TH-Toughness total ; DO-Dissolved oxygen; $\mathrm{pH}$-Potential Hydrogen; $\mathrm{NH}_{4}$-Ammonium; $\mathrm{NH}_{3}$-Nitrate; $\mathrm{Ca}_{\text {total }}$-Total calcium; $\mathrm{OC}_{\text {total }}$-Total organic carbon; $\mathrm{Cu}_{\text {total }}$-Total copper; $\mathrm{Fe}_{\text {total }}$-Total iron; $\mathrm{P}_{\text {total }}$-Total phosphorus; $\mathrm{Mg}_{\text {total }}$-Total magnesium; $\mathrm{Mn}_{\text {total }}-\mathrm{Total}^{-}$ manganese; $\mathrm{Na}_{\text {total }}$-Total sodium; $\mathrm{Zn}_{\text {total }}$-Total zinc; TS-Total solids; TDS-Total dissolved solids; $\mathrm{C}_{\text {total }}$-Total coliforms e $\mathrm{C}_{\text {therm }}$-Thermotolerant coliforms; * Liquor stream: Source (PL1); Before (PL2); After (PL3) e Wine stream: Source (PW1); Before (PW2) e After (PW3)

thus suggesting a greater contribution of diffuse sources in reducing the quality of water. Of the existing relationships, that of EC with TDS and TS stands out in the same quadrant. These results agree partially with those found by Rocha and Pereira (2016), who also found a direct relationship of Color with DS, which was not observed in this study. They also emphasized the relationship of DO with Color and Turbidity, results similar to the arrangement found in the "Liquor stream". The arrangement of the variables Turbidity, $\mathrm{OC}_{\text {total, }}$ and Color occurred in P1 of the "Liquor stream". The highest variation of the data justified the position of Turbidity.

The biological variables plotted $\mathrm{C}_{\text {total }}$ and $\mathrm{C}_{\text {therm }}$ are located in the same quadrant of Figure 3 and corresponded to the highest values found in the "Liquor stream". As postulated by Nascimento and Alencar (2014), these organisms represent water contamination by animal and human feces, which are usually unduly deposited in water sources (Dias and Gazzinelli, 2014).

In the "Liquor stream", the reduction in water quality proves to be more intense from wastewater, while in the "Wine stream", it is associated more effectively with runoff water and the privileged local geology.

\section{Conclusions}

The water quality in the "Liquor stream" shows significant oscillations and impacts the environment after the source. The diffuse sources of water quality reduction in the "Liquor stream" are mainly due to wastewater from the agroindustry and nearby residences.

The "Wine stream" source shows the highest values of alkalinity, electrical conductivity, total hardness, and total calcium. The sources of water pollution are associated more effectively with agricultural activities than with agroindustry activity.

The chemical and biological oxygen demand, dissolved oxygen, total iron, total manganese, and total phosphorus presented values above those stated in resolution $\mathrm{N}^{\mathrm{o}} 357$ of the National Environment Council in both streams of the agroindustry.

Therefore, the small agribusinesses need to adequate their waste treatment systems, as well as reduce their diffuse sources of pollution. 


\section{Literature Cited}

Ahmed, O.; Sulieman, A.M.E.; Elhardallou, S.B.

2013. Physicochemical, Chemical and Microbiological Characteristies of Vinasse, A. By-product from Ethanol Industry. American Journal of Biochemestry. 3(3): 80-83. Alves, E.C.; Silva, C.F. da; Cossich, E.S.; Tavares, C.R.G.; Filho, E.E. de S.; Carniel, E.

2008. Water quality evaluation of the Pirapó river basin Maringá, Paraná, State, through physical, chemical and microbiologic parameters. Acta Sci. Technol. Maringá, 30(1): 39-48.

Andrade, S.O.; Oliveira, A.M.B.M. de; Coelho, L.F. de O.; Brito, C.S.de; Valério, R.A.; Ferreira, D.de M.; Lima, Y.S.

2016. Social and environmental impacts of rural family farms in the Brazilian semi-arid northeast. Revista Brasileira de Gestão Ambiental. (Pombal - PB - Brasil) 10(1): 07-16.

Apha; Awwa; Wpcf.

2005. Standard methods for the examination of water and wastewater, 21 ed. Washington, D.C.: American Public Health Association, American Water Works Association, Water Environment Federation.

Ayres, M.; Ayres Júnior, M.; Ayres, D.L.; Santos, A.A.S.; Ayres, L.L. BioEstat.

2016. Versão 5.0, Sociedade Civil Mamirauá, MCT - CNPq, Belém, Pará, Brasil.. Available: <http://bioestat.software. informer.com/5.0/>. Consulted:: 27 Ago/2016.

Antunes, J.V.M; Carminate, B; Bonomo, R; Oliveira, M.A.

2012. Biological monitoring of water quality of cricarè river for use in irrigation vegetable. Revista Enciclopédia Biosfera, Goiânia, 8(15): 2483-2491.

CONAMA.

2015. -Resolução $N^{\circ} 357.17$ de março de 2005. Conselho Nacional do Meio Ambiente. Ministério do Meio Ambiente, 23 p.

Correia, W.; Silva, A.F.G. da; Batista-Silva, V.F.; Bailly, D.;

Ruaro, R.; Helfenstein, A.L.Z.

2015. Water qualit y of a stream subject to the release of industrial effluent in an environmental protected area. Revista em Agronegócio e Meio Ambiente, Maringá(PR), 8(esp): 9-25.

Costa, F.B.; Ferreira, V.de O.

2015. Analysis of parameters that composing the water quality index (wqi) in the portion of the Minas Gerais state of the PARANAIIBA RIVER basin. Revista Eletrônica de Geografia, 7(18): 22-47.

Dias, B.C.O.; Gazzinelli, S.E.P.

2014. Assessment and identification of parasitic forms in lettuce (Lactuca sativa) in São Roque, São Paulo State, Brazil. Scientia vitae, 1(3): 27-34.

Fia, R.; Tadeu, H.C.; Menezes, J.P.C.; Fia, F.R.L.; Oliveira, L.F.C. 2015. Water quality of an urban lotic ecosystem. Revista Brasileira de Recursos Hídricos, 20(1): 267-275.

Gutiérrez, G.E.; Evers, P.M.; Otterpohl, R.; Limas, J.C.P.; Cárdenas, R.M.Z.; Torres, L.G.

2015. Evaluación de las infiltraciones al sistema de drenaje mediante análisis comparativo de la concentración de contaminantes en agua residual. Caso de estudio en Tepic, México. Revista internacional de contaminación ambiental. 31(1): 89-98.
Lima, R.N. de S.; Ribeiro, C.B. de M.; Barbosa, C.C.F.; Filho, O.C.R.

2016. Study of point and diffuse pollution in the Funil reservoir hydropower plant contribution basin using spatially distributed Geographic Information System modeling. Engenharia Sanitária Ambiental. 21(1): 139-150.

Menezes, J.P.C.; Bittencourt, R.P.; Farias, M. de S.; Bello, I.P.;

Fia, R.; Oliveira, L.F.C. de.

2016. Relationship between patterns of use and occupation of soil and water quality in an urban watershed. Engenharia Sanitária Ambiental. 21(3): 519-534.

Nascimento, E.D.; Alencar, F.L.S.

2014. Antimicrobial and antiparasitic efficiency of desinfectants in the sanitation of vegetables in Natal city - RN. Ciência e Natura, 36(2): 96-106.

Nascimento, B.L.M.; Gomes, D.R.C.de S.; Costa, G.P.; Araújo, S.S.; Santos, L.C.A. dos; Oliveira, J.D. de.

2015. Behavior and evaluation of potentially toxic metals $(\mathrm{Cu}$ (II), $\mathrm{Cr}$ (III), $\mathrm{Pb}$ (II) and $\mathrm{Fe}(\mathrm{III})$ ) in surface waters of streams Capivara and streams Bacuri Imperatriz-MA, Brazil. Engenharia Sanitaria Ambiental. 20(3): 369-378.

Ortegón, G.P.; Arboleda F.M.; Candela, L.; Tamoh, K.; Valdes-

Abellan, J.

2016. Vinasse application to sugar cane fields. Effect on the unsaturated zone and groundwater at Valle del Cauca (Colombia). Science of The Total Environment. 539: 410-419.

Pereira, B.W. de F.; Maciel, M. de N.M.; Oliveira, F. de A.; Alves, M.A.M. da S.; Ribeiro, A.M.; Ferreira, B.M.; Ribeiro, E.G.P. 2016. Land use and water quality degradation in the Peixe-Boi River watershed. Revista Ambiente \& Água. 11(2): 472-485.

Pinheiro, A.; Schoen, C.; Schultz, J.; Heinz, K.G.H.; Pinheiro, I.P.; Deschamps, F.C.

2014. Relationship Between Land Use and Water Quality in River Basin Rural in the Atlantic Forest biome. Revista Brasileira de Recursos Hídricos, 19(3): 127-139.

Rixen, T.; Baum, A.; Sepryany, H.; Pohlman, T.; Jose, C.; Samiaji, J.

2012. Dissolved oxygen and its response to eutrophication in a tropical black water river. Journal of Environmental Management, 91(8): 1730-1737.

Rocha, C.H.B.; Pereira, A.M.

2016. Multivariate Analysis for selection of monitoring parameters in water reservoir of Juiz de Fora, Minas Gerais. Revista Ambiente \& Água. 11(1): 176-187.

Rocha, C.H.B.; Silva, T.M. da; Freitas, F.A.

2016. Conditioning processes of changes in limnological variables: a statistical approach in the dam of São Pedro, Juiz de Fora (MG), Brazil. Engenharia Sanitaria Ambiental. 21(1):131-138.

Souza, M. de; Pinto, F.G. da S.; Frueti, T.K.; Piana, P.A.; Moura, A.C.de.

2014. Water quality indicators for environmental and resistance profile of Escherichia coli strains isolated in Rio Cascavel, Paraná, Brazil. Engenharia Agrícola, 34(2): 352-362.

Statsoft Inc. Statistica.

2004. (Data analysis software system). Version 7. Available: http://www.statsoft.com.

Zúñica, V.C.; Gandini, A.; Andrés, M.

2013. Caracterización ambiental de las vinazas de residuos de caña de azúcar resultantes de la producción de etanol. Byna, 80(117): 124-131. 